\title{
Functional Interactions between Tumor and Peripheral Nerve: Morphology, Algogen Identification, and Behavioral Characterization of a New Murine Model of Cancer Pain
}

\author{
Paul W. Wacnik, ${ }^{1}$ Laura J. Eikmeier, ${ }^{2}$ Timothy R. Ruggles, ${ }^{2}$ Margaret L. Ramnaraine, ${ }^{3}$ Bruce K. Walcheck, ${ }^{2}$ \\ Alvin J. Beitz, ${ }^{2}$ and George L. Wilcox ${ }^{1,4}$ \\ Departments of ${ }^{1}$ Pharmacology, ${ }^{2}$ Veterinary Pathobiology, ${ }^{3}$ Orthopedic Surgery, and ${ }^{4}$ Neuroscience, University of \\ Minnesota Schools of Medicine and Veterinary Medicine, Minneapolis, Minnesota 55455
}

This paper describes a model of tumor-induced bone destruction and hyperalgesia produced by implantation of fibrosarcoma cells into the mouse calcaneus bone. Histological examination indicates that tumor cells adhere to the bone edge as early as post-implantation day (PID) 3 , but osteolysis does not begin until PID 6, correlating with the development of hyperalgesia. $\mathrm{C} 3 \mathrm{H} / \mathrm{He}$ mice exhibit a reproducible hyperalgesia to mechanical and cold stimuli between PID 6 and 16. These behaviors are present but significantly reduced with subcutaneous implantation that does not involve bone. Systemic administration of morphine $\left(E D_{50} 9.0 \mathrm{mg} / \mathrm{kg}\right)$ dose-dependently attenuated the mechanical hyperalgesia. In contrast, bone destruction and hypersensitivity were not evident in mice implanted with melanoma tumors or a paraffin mass of similar size. A novel microperfusion technique was used to identify elevated levels of the putative algogen endothelin (ET) in per- fusates collected from the tumor sites of hyperalgesic mice between PID 7 and 12. Increased ET was evident in microperfusates from fibrosarcoma tumor-implanted mice but not from melanoma tumor-implanted mice, which are not hyperalgesic. Intraplantar injection of ET-1 in naive and, to a greater extent, fibrosarcoma tumor-bearing mice produced spontaneous pain behaviors, suggesting that ET-1 activates primary afferent fibers. Intraplantar but not systemic injection of the ET-A receptor antagonist BQ-123 partially blocked tumor-associated mechanical hyperalgesia, indicating that ET-1 contributes to tumor-induced nociception. This model provides a unique approach for quantifying the behavioral, biochemical, and electrophysiological consequences of tumor-nerve interactions.

Key words: hyperalgesia; primary afferent fibers; tumor nociception; endothelin; cancer pain; tumor microperfusion
Pain is often the first indication of tumor presence or recurrence (Caraceni and Portenoy, 1999) and is present in $80 \%$ of cancer patients at death (Reale et al., 2001). Metastasis to bone, often with adjacent soft tissue involvement, is thought to be the most common cause of cancer-related pain (Banning et al., 1991; Mercadante, 1997; Reale et al., 2001). Clinical evidence indicates that tumors cause pain in bone and soft tissues via nerve compression, the release of chemical algogens, and $\mathrm{pH}$ changes, whereas pain from microfractures and stretching of the periosteum are unique to bone (Mercadante, 1997). Despite an extensive literature regarding cancer pain assessment and management, our understanding of the basic mechanisms that underlie the production of pain associated with malignancy is meager at best. An understanding of these basic mechanisms is essential for the development of better therapeutic approaches to cancer pain treatment,

Received June 11, 2001; revised Aug. 8, 2001; accepted Aug. 14, 2001.

This work was supported by seed funding from the University of Minnesota Academic Health Center and National Institutes of Health (NIH) Grant R01CA84233-01 to A.J.B. This grant and NIH Grant R01-CA91007-01 partially support G.L.W. P.W.W. was supported by National Institute of Dental Research training Grant DE07288, and L.J.E. was supported by National Institute on Drug Abuse training Grant DA07239. We thank Melanie Gipp for technical assistance, University of Minnesota Cancer Center for support of the tissue culture facility, and Drs. Don Simone and David Cain for helpful comments during the preparation of this manuscript.

P.W.W. and L.J.E. contributed equally to this work.

Correspondence should be addressed to Dr. George L. Wilcox, Departments of Neuroscience and Pharmacology, University of Minnesota, 6-120 Jackson Hall, 321 Church Street SE, Minneapolis, MN, 55455-0217. E-mail: george@umn.edu. Copyright (C) 2001 Society for Neuroscience $0270-6474 / 01 / 219355-12 \$ 15.00 / 0$ but efforts to gain such information are hampered by the lack of adequate animal tumor models. Recently, Schwei et al. (1999) described a femur model of bone cancer pain that allowed characterization of neurochemical changes in the spinal cord associated with development of tumor-induced nociception. Although the femur bone tumor model provides a valuable archetype to assess CNS changes, it is difficult to examine algogen release, quantify primary hyperalgesia, and perform electrophysiological analysis of primary afferent fibers innervating the tumor, bone, and other deep tissues in these mice. Here we report on the development of a hindpaw tumor model that incorporates both bone and adjacent soft tissue involvement to produce a localized cancer pain that lends itself more readily to behavioral, electrophysiological, and peripheral neurochemical analysis.

Tumor cells are known to secrete a variety of different substances (Hall, 1997; Chirgwin and Guise, 2000), many of which are potential algogens. One of the goals of the present study was to examine the putative role of one of these mediators, endothelin-1 (ET-1), in the induction of cancer pain in the hindpaw tumor model. Endothelin is a 21 amino acid peptide derived from a larger precursor, big-endothelin, by action of endothelinconverting enzyme; three isoforms of endothelin, named ET-1, ET-2, and ET-3, have been identified (Rubanyi and Polokoff, 1994). ET-1, generated by a number of cell types and a number of tumor cell lines, exerts various important biological actions mediated by two receptor subtypes, $\mathrm{ET}_{\mathrm{A}}$ and $\mathrm{ET}_{\mathrm{B}}$ (Gandhi et al., 1994; Webb, 1997). Ferreira et al. (1989) were among the first to show that ET-1 participates in the production of inflammatory 
pain. Subsequently all three isoforms of ET were shown to elicit an abdominal constriction response in mice, ET-2 being the most potent (Raffa and Jacoby, 1991). Since these initial studies, a role for ET in nociception has been well documented (Davar et al., 1998; De-Melo et al., 1998; Piovezan et al., 1998, 2000; Fareed et al., 2000), and both receptor subtypes have been shown to participate in ET-induced nociception (Raffa et al., 1996). The present study targets the peptide ET-1 and tests the hypothesis that it participates in the production of bone tumor pain.

\section{MATERIALS AND METHODS}

\section{Animals}

A total of $313 \mathrm{C} 3 \mathrm{H} / \mathrm{He}$ and $42 \mathrm{~B} 6 \mathrm{C} 3 \mathrm{fe} / 1$ mice (National Cancer Institute) aged $8-10$ weeks and weighing $24-28$ gm were used in all fibrosarcoma or mixed melanoma/fibrosarcoma experiments, respectively. The inbred mouse strain $\mathrm{C} 3 \mathrm{H} / \mathrm{He}$ is syngeneic to the fibrosarcoma cells used in these experiments and allows these cells to grow tumors without rejection (Clohisy et al., 1996). The B6C3fe/1 mice, the F1 cross between $\mathrm{C} 57 \mathrm{BL} / 6$ and $\mathrm{C} 3 \mathrm{H} / \mathrm{He}$ strains, readily accept both fibrosarcoma $(\mathrm{C} 3 \mathrm{H} / \mathrm{He}$ origin) and melanoma ( $\mathrm{C} 57 \mathrm{BL} / 6$ origin) cells, allowing direct comparison of the effects of these tumor types. Mice were housed in boxes of $8-10$ in a temperature- and humidity-controlled environment and maintained on a $12 \mathrm{hr}$ light/dark cycle with ad libitum access to mouse chow and water. All experimental protocols were approved by the Animal Care and Use Committee of the University of Minnesota.

\section{Cell culture and implantation}

National Collection of Type Cultures (NCTC) clone 2472 fibrosarcoma cells, originally derived from a connective tissue tumor in a $\mathrm{C} 3 \mathrm{H}$ mouse, were obtained from the American Type cell Culture Collection (Rockville, MD). G3.26 cells, a B6 subclone melanoma cell, originally derived from a C57BL/6 mouse, were obtained from Dr. Christopher W. Stackpole (New York Medical College, Valhalla, NY) (Stackpole et al., 1985). All cells were maintained as described previously (Clohisy et al., 1996). Just before implantation, cells were counted with a hemacytometer, pelleted, resuspended, rinsed in PBS, pelleted a second time, and then resuspended in PBS for implantation.

Mice were placed in an enclosed chamber and anesthetized with $2 \%$ halothane in preparation for cell implantation. When the animal demonstrated nonresponsiveness to paw pinch, it was removed from the chamber and fitted with a facemask that continuously delivered $2 \%$ halothane in an air/oxygen mixture throughout the procedure. Cells $(2 \times$ $10^{5}$ fibrosarcoma or $1.5 \times 10^{5}$ melanoma) in a volume of $10 \mu \mathrm{l}$ of PBS were injected unilaterally into the heel using a 29 gauge, sterile single-use needle attached to a $0.3 \mathrm{ml}$ insulin syringe (Becton Dickenson) to manually bore through the calcaneus bone. Sham mice underwent the identical procedure with the exception that PBS alone was injected. Fibrosarcoma cells were implanted subcutaneously external to the bone in one group of mice for comparison. Mice that showed signs of motor dysfunction at any point after tumor implantation were euthanized and not included in the study. Control mice were anesthetized, and paraffin $(60-100 \mu \mathrm{l})$ or equally warm saline $\left(53^{\circ} \mathrm{C}\right)$ was injected subcutaneously into the heel using a heated 27 gauge needle and syringe to produce a nonmalignant mass approximately the size of a post-implantation day (PID) 10 fibrosarcoma tumor.

\section{Tumor histology}

At days 3, 6, 9, and 12 after tumor implantation, mice were deeply anesthetized with $100 \mathrm{mg} / \mathrm{kg}$ sodium pentobarbital and transcardially perfused with $15 \mathrm{ml}$ of cold PBS followed by $30 \mathrm{ml} 4 \%$ paraformaldehyde. Both hindpaws were removed and post-fixed for $4 \mathrm{hr}$ in $4 \%$ paraformaldehyde and then transferred to decalcifying solution $(0.003 \mathrm{M}$ EDTA, $1.35 \mathrm{~N} \mathrm{HCl})$ for $24 \mathrm{hr}$. The tissue was rinsed, dehydrated, and paraffin-embedded, cut into $5 \mu \mathrm{m}$ cross sections using a rotary microtome, and stained with hematoxylin and eosin. Sections through both the ipsilateral hindpaw containing the tumor and the contralateral hindpaw were examined histologically under bright-field microscopy. Sections were examined for the presence and degree of bone destruction and for evidence of immune cell infiltration.

\section{Tumor size and calcaneus thickness}

Both the melanoma and fibrosarcoma were localized and formed a mass in the region of the injection site with the fibrosarcoma tumors forming a particularly even sphere around the heel. Therefore, the relative tumor (days 3-15) and paraffin bleb (days 1-7) sizes were determined by measurement of the heel width. Measurements were taken after behavioral testing in the following manner. Mice were held by the tail and allowed to grasp a wire mesh, leaving their hindpaws free while a micrometer was positioned over the heel and the diameter of the tumor was measured percutaneously. On PID 15, mice were killed; tumor/ connective tissue was carefully removed from the remaining calcaneus bone, and the maximum diameter of the remaining bone was measured with a micrometer.

\section{Behavioral methods}

\section{Mechanical hyperalgesia assay}

Withdrawal responses evoked by mechanical stimuli were obtained in tumor-bearing mice and compared with sham-treated animals at several time points after implantation as well as in a series of pharmacological experiments described below. Groups of mice were prescreened for hypersensitivity with a von Frey monofilament, $3.4 \mathrm{mN}(\mathrm{C} 3 \mathrm{H} / \mathrm{He}$ mice $)$ or $1.6 \mathrm{mN}$ (B6C3fe/1 mice) bending force, and high responders (responses of $\geq 50 \%$ before treatment) were removed from further experimentation $(<5 \%$ of mice). The $3.4 \mathrm{mN}$ monofilament was used in the $\mathrm{C} 3 \mathrm{H} / \mathrm{He}$ mice because their responses to this monofilament were reproducible and sufficiently large to allow detection of dose-dependent attenuation by analgesics or ET-1 antagonists (Wacnik et al., 2000).

Baseline values for mechanical sensitivity were determined for each animal $4 \mathrm{~d}$ before, $1 \mathrm{~d}$ before, and on the day of implantation (cellimplanted and sham groups) or immediately before analgesic/antagonist administration; testing was repeated throughout the time course of each study. Briefly, animals were placed on a wire mesh platform, covered with a hand-sized container, and allowed to acclimate to their surroundings for a minimum of $30 \mathrm{~min}$ before testing. The monofilament was applied to the point of bending six times on the plantar surface of each hindpaw for tumor time course studies. In pharmacological studies (morphine, cycloheximide, and ET-1 antagonists), the monofilament was applied 10 times on the paw ipsilateral to the tumor. The number of vigorous responses to the monofilament was counted and expressed as percentage of stimuli giving rise to a withdrawal response.

\section{Cold hyperalgesia assay}

The same groups of mice were tested for cold hyperalgesia after determining responses to mechanical stimuli using a constant temperature cold plate repeatedly over time as tumors grew. The cold plate consisted of an aluminum test surface $(10 \times 15 \mathrm{~cm})$ enclosed in a clear Plexiglas container $\left(20 \mathrm{~cm}\right.$ high) maintained at $3 \pm 1^{\circ} \mathrm{C}$ by a thermostatically controlled water bath and circulating pump. After placing the mouse on the cold plate, the experimenter counted the frequency of withdrawal responses over a 4 min period. A withdrawal response included one or more of the following behaviors: hindpaw held above the cold plate (one response per second), shaking or licking a hindpaw (one response per activity), or whole mouse jumps (one response per leap). This cold hyperalgesia protocol is based on a rat model used to analyze hyperresponsiveness in inflammatory (complete Freund's adjuvant) and neuropathic (chronic constriction injury) experimental hyperalgesia models (Jasmin et al., 1998).

\section{In vitro and in vivo analysis of endothelin secretion}

As part of our investigation of endothelin and its potential role in tumor-induced pain, we conducted three experiments to measure (1) relative levels of ET secreted by tumor cells in vitro, (2) relative concentration of ET in homogenates of developing hindpaw tumors, and (3) relative concentration of ET secreted by tumor cells in vivo at various time points after implantation. The level of ET secreted by tumor cells in vitro was determined by growing cells in serum-free media for $24 \mathrm{hr}$ and subsequently analyzing ET levels in the culture media (conditioned media). Whole-tumor levels were determined by harvesting and homogenizing tumors and then evaluating relative ET levels in homogenate supernatants, whereas the level of ET secreted into the extracellular fluid of the tumor in vivo was sampled by microperfusion, as detailed below. Homogenate samples were collected at PID 5-12, and microprobe samples were collected at PID 8-13. All tumor samples were taken from mice that exhibited mechanical hyperalgesia at the given time points.

\section{ET levels in tumor cell cultures}

Tumor cell cultures (cell lines 2472 and G3.26) were grown in serum-free media for $24 \mathrm{hr}$, at which time the cells were at equal confluency. Three 
milliliters of conditioned media were collected and centrif uged for 20 min at $1000 \mathrm{rpm}$, and the supernatant was aliquotted and frozen at $-80^{\circ} \mathrm{C}$ until time of analysis. ET concentration was compared between conditioned and unconditioned media (media not incubated with cells).

\section{ET levels in tumor homogenates}

Hindpaw tumors were dissected away from the surrounding connective tissue. Normal tissue from a comparable area of the contralateral hindpaw was collected for comparison. Samples were placed in ice-cold buffer (PBS with $0.4 \mathrm{~m} \mathrm{NaCl}, 0.05 \%$ Tween 20, 0.5\% NGS, $0.1 \mathrm{~mm}$ phenylmethylsulfonyl fluoride, $0.1 \mathrm{~mm}$ benzethonium chloride, $10 \mathrm{~mm}$ EDTA, and $1 \%$ protease inhibitor mixture) and finely minced with a scissors. The tissue suspension was ground with a disposable pestle (Fisher Scientific, Houston, TX) and then centrifuged at 15,000 rpm for $30 \mathrm{~min}$ at $4^{\circ} \mathrm{C}$. The supernatant was aliquotted and frozen at $-80^{\circ} \mathrm{C}$ until the time of analysis.

\section{ET in tumor extracellular fluid}

Microprobe design. Microdialysis, traditionally used to sample low molecular weight substances from extracellular fluid, has limited ability to dialyze proteins and peptides. In practice, a membrane with a $20 \mathrm{kDa}$ molecular weight cutoff (MWCO, Gambro Hospel Ltd., Huntingdon, $\mathrm{UK}$ ) yields significant transport only at and below $5 \mathrm{kDa}$. Moreover, some proteins such as tumor necrosis factor $\alpha(\mathrm{TNF} \alpha)$ and nerve growth factor (NGF) adhere to the microdialysis membrane, further limiting their passage through the membrane. Therefore, we developed and applied a perfusion microprobe consisting of a 23 gauge stainless steel hypodermic needle with a $2 \mathrm{~mm}$ opening in the middle, extending a "push-pull" microperfusion design based on the procedure recently described by Patterson et al. (2001). This microprobe design allowed increased and reproducible peptide/protein yields and increased mechanical stability and durability.

In vitro testing of the microprobe. We compared in vitro recoveries of ET-1 between traditional microdialysis ( $20 \mathrm{kDa}$ MWCO probe) and push-pull microperfusion techniques using a modified Ringer's solution at a flow rate of $3 \mu \mathrm{l} / \mathrm{min}$ for dialysis (Renno et al., 1998) and $10 \mu \mathrm{l} / \mathrm{min}$ (push) with $20 \mu \mathrm{l} / \mathrm{min}$ (pull) for microperfusion (Patterson et al., 2001). Both techniques used peristaltic pumps (Rabbit Plus, Rainin Instrument Co). In vitro microperfusion and microdialysis techniques were compared by determining the percentage recovery of ET-1 or bovine serum albumin (BSA) from a $100 \mu \mathrm{g} / \mathrm{ml}$ solution of these substances in a restricted region of a Petri dish delineated with a hydrophobic barrier (Pap Pen, Research Products International, Natick, MA).

Microperfusion of tumors. To examine levels of ET in the extracellular fluid of the hindpaw fibrosarcoma, we implanted a microprobe into the tumor site or into a comparable site in control animals. This procedure is terminal so that each mouse contributes data to a single time point. Preliminary studies showed no difference in ET release in naive versus sham-injected animals at all time points examined; therefore, naive animals were used as controls in the microperfusion experiments. A small amount of heparin $(2 \mu \mathrm{l})$ prevented clotting in the microprobe. Mice were anesthetized initially with $0.6 \mathrm{mg}$ acepromazine and $10 \mathrm{~min}$ later with $40 \mathrm{mg} / \mathrm{kg}$ Nembutal. When nociceptive withdrawal and eyeblink reflexes were absent, the microprobe was inserted through the center of the tumor site and secured to the skin with super glue. Two lengths of polyethylene tubing (PE-10, prefilled with heparin-nPBR; 30 $\mathrm{U} / \mathrm{ml}$ ) connected the microprobe to the fluid swivel and two peristaltic pumps. The inlet perfusion pump pushed modified Ringer's through the microprobe at a rate of $10 \mu \mathrm{l} / \mathrm{min}$; the outlet pump was set at a rate of 20 $\mu \mathrm{l} / \mathrm{min}$ (as determined from in vitro experiments), which pulled at an effective rate of $10 \mu \mathrm{l} / \mathrm{min}$ in vivo. Preliminary experiments had determined that this setting on the outlet pump maintained a constant pressure at the microprobe opening and prevented clogging of the probe. After 45 min equilibration and awakening, samples were collected for a period of 3-4 hr, centrifuged to assess the amount of red blood cells (micrograms per milliliter), augmented with a protease inhibitor mixture (Sigma, St. Louis, MO; concentration $=0.00014 \%$, based on manufacturer's recommendation), and stored at $-80^{\circ} \mathrm{C}$ for later analysis.

\section{Quantification of ET using microbead immunosorbent assay}

The following microbead immunosorbent assay (MBISA) was used to measure ET levels in all release and homogenate studies. The use of flow cytometry has recently been adapted to evaluate the presence of solubilized proteins that have been immobilized on polystyrene beads (Curt- singer et al., 1997), and we have adapted this method to determine relative levels of individual proteins in a mixture. The adapted procedure is cost effective and efficient, requires very little sample, and allows analysis of multiple proteins from single samples. Briefly, beads $(4 \mu \mathrm{m}$ sulfate polystyrene; Interfacial Dynamics, Portland, OR) are coated with proteins and peptides contained in a sample. The protein of interest is labeled with a fluorophore, and the beads are subjected to flow cytometry. Previous experiments indicated a linear relationship between the amount of a known protein bound to the bead and the fluorescence intensity of the beads (data not shown).

Analysis was begun by incubating $1 \mu \mathrm{l}$ of conditioned cell culture medium in $9 \mu \mathrm{l}$ of Dulbecco's PBS or $10 \mu \mathrm{l}$ of perfusate (average total protein of $3 \mu \mathrm{g})$ with $10^{7}(1 \mu \mathrm{l})$ beads overnight at $4^{\circ} \mathrm{C}$. To ensure equal loading of protein onto beads between tumor homogenates, a total protein concentration was determined (Coomassie Plus, Pierce, Rockford, IL), and $10 \mu \mathrm{g}$ of protein in a volume of $10 \mu \mathrm{l}$ was incubated with $10^{7}$ beads for $2 \mathrm{hr}$ at room temperature. After the sample incubation period, the beads with bound protein from conditioned medium, perfusate samples, and homogenates were treated identically. Nonspecific binding to the beads was blocked with PBS containing $1 \%$ normal goat serum and $5 \mathrm{~mm}$ sodium azide (FACS wash buffer) for $30 \mathrm{~min}$ at room temperature. Beads were centrifuged at $14,000 \mathrm{rpm}$ for $3 \mathrm{~min}$, supernatant was discarded, and the bead pellet was resuspended in $20 \mu \mathrm{l}$ of FACS wash buffer. Ten microliters of resuspended beads were added to rabbit anti-mouse ET serum (1:1000; Sigma), and $10 \mu \mathrm{l}$ was added to control serum (1:1000 normal rabbit serum) and incubated at room temperature for $1 \mathrm{hr}$. The primary antibody used in this study recognizes all three forms of ET (ET-1, ET-2, and ET-3). We also used a separate antibody that is specific to ET-3 to determine whether ET-3 levels are specifically elevated in tumor microperfusates.

Beads were pelleted and washed with FACS wash buffer, resuspended, and incubated with FITC-conjugated goat-anti-rabbit Ig (1:100; Jackson ImmunoResearch Laboratories, West Grove, PA) for $1 \mathrm{hr}$ at room temperature. Beads were pelleted, washed, and resuspended in FACS wash for analysis. For these assays, the mean fluorescence intensity (MFI) of 5000 beads was determined using a flow cytometer (FACSCalibur, Becton Dickinson, Mountain View, CA). The net mean fluorescence was determined by subtracting the MFI of antibody isotype control-incubated beads from the MFI of beads incubated with ETspecific antibodies. Because previous experiments (data not shown) have demonstrated that the resulting net MFI is linearly correlated with the ET concentration, MFI was used for statistical analyses.

\section{ET-1-induced nociception}

Mice were placed on a wire mesh platform, covered with a hand-sized container, and allowed to acclimate to their surroundings for a minimum of $30 \mathrm{~min}$ before testing. ET-1 (4.0 pmol-1.2 nmol/30 $\mu \mathrm{l}$; American Peptide Co., Sunnyvale, CA) or vehicle was injected into the tumor site or subcutaneously into the heel of control (naïve) mice, and the cumulative licking responses directed to the hindpaw were counted over a 10 min period. Injecting a volume of $30 \mu \mathrm{l}$ assured that both the tumor and surrounding tissue were bathed in the drug or vehicle. The duration of observation of licking time was chosen on the basis of preliminary studies showing that the majority (64\%) of nocifensive behaviors occurred in the first $10 \mathrm{~min}$ of a $20 \mathrm{~min}$ test period. ET- 1 was dissolved at $1 \mathrm{mg} / \mathrm{ml}$ in $1 \%$ $\mathrm{NaHCO}_{3}$, and further dilutions to appropriate concentrations were made in sterile saline so that vehicle for control experiments ranged from 0.001 to $0.3 \% \mathrm{NaHCO}_{3}$ in sterile saline (ET-1, $4.0 \mathrm{pmol}-1.2 \mathrm{nmol} / 30 \mu \mathrm{l}$ ).

\section{Inhibition of tumor-induced nociception}

\section{Withdrawal responses after mechanical stimuli}

Mechanical hyperalgesia was used to evaluate tumor-induced nociception (pre-drug baseline) and to measure the analgesic effect of selected inhibitors. The advantage of testing mechanical sensitivity with von Frey monofilaments is that it allows several post-drug measurements to be made without handling the mouse, permitting time-dependent and dosedependent analysis in tumor-implanted mice. When tumor-induced mechanical hyperalgesia was evident, each $\mathrm{C} 3 \mathrm{H} / \mathrm{He}$ mouse was tested before and after drug administration with the $3.4 \mathrm{mN}$ von Frey monofilament 10 times on the plantar surface of the ipsilateral paw; mice with responses $>50 \%$ and with no signs of skin lesions were included in the analgesic/antagonist studies. The degree of drug-induced inhibition of mechanical hypersensitivity was determined relative to the pre-drug baseline. Percentage inhibition was calculated using the following for- 
mula: $\%$ inhibition $=(\%$ response pre-drug $-\%$ response post-drug $) \times$ $100 / \%$ response pre-drug.

The $\mathrm{ED}_{50}$ values and $95 \%$ confidence limits were calculated according to the method of Tallarida and Murray (1987). This protocol and analysis have been reproduced in multiple experiments to measure dosedependent attenuation of tumor-induced mechanical hyperalgesia (Wacnik et al., 2000) by the analgesics morphine and clonidine, as reported previously (Fairbanks et al., 2000).

\section{Morphine}

The activity of morphine as an analgesic was tested in this model to support the idea that a hyperalgesic condition underlies the behavior. Hyperalgesic mice (PID 15) were administered morphine systemically (3-30 mg/kg, i.p.) and tested again $30 \mathrm{~min}$ after administration, and the percentage inhibition was calculated. This morphine dose range was based on previous work (Wacnik et al., 2000) in which mechanical hyperalgesia produced by fibrosarcoma tumors in the femur was attenuated.

\section{Cycloheximide}

To test for inhibition of mechanical hypersensitivity induced by putative peptidergic algogens secreted at the tumor site, the protein synthesis inhibitor cycloheximide $(150 \mu \mathrm{g} / 10 \mu \mathrm{l}$ PBS $)$ was injected into the tumor site of PID 8 hyperalgesic mice. Mice were tested again 0.5, 2, 4, 6, 8, 12, and $24 \mathrm{hr}$ after cycloheximide administration, and the percentage inhibition was calculated.

\section{ET receptor antagonists}

To determine whether ET contributes to tumor-evoked mechanical hyperalgesia and to determine the receptor types responsible, the ET-A receptor antagonist BQ-123 [0.16-16 nmol/30 $\mu \mathrm{l}$ PBS, c(D-Trp-D-AspPro-D-Val-Leu); American Peptide Co., Sunnyvale, CA], the ET-B receptor antagonist BQ-788 (0.16-48 nmol/30 $\mu \mathrm{l}$ PBS, $N$-cis-2,6-dimethylpiperidinocarbonyl-L- $\gamma$-methylleucyl-D-1-methoxycarbonyltrptophanylD-Nle; American Peptide Co.) or saline was administered into the tumor of hyperalgesic mice at PID 10. Mice were tested 45 and 180 min after ET-1 antagonist administration, and the percentage inhibition was calculated. Injecting a volume of $30 \mu \mathrm{l}$ assured that the tumor and the surrounding paw were bathed in drug or vehicle. Antagonist testing was conducted at a time after implantation when both microperfusion and homogenate levels of ET where found to be elevated (PID 10).

\section{Statistical analysis}

Mean withdrawal response frequency to mechanical stimuli, cold-plate responses, and ET-induced nocifensive behaviors as well as mean fluorescence intensity data were analyzed by repeated-measures ANOVA; Bonferonni or Fisher's PSLD post hoc comparisons were used for behavioral time course and fluorescence intensity data as appropriate to determine significance across the tumor time course analysis using StatView 5.0 (SAS Institute). Data are presented as mean and SEM for treatment groups. Statistical significance is reported for $p<0.05$ except as noted.

\section{RESULTS}

\section{Tumor morphology}

Histological examination of fibrosarcoma tumors revealed a nonencapsulated tumor mass consisting of spindle-shaped cells (Fig. $1 B$ ), characteristic of a fibrosarcoma. As early as PID 3, tumor cells adhered to the bone edge, but osteolysis was not evident until PID 6 (Fig. 1). Bone destruction progressed through PID 12, as indicated by increasing irregularity of the bone edge as well as decreasing bone thickness and eventual breakthrough. At PID 6 , 9 , and 12 , nerves within the tumor mass could be identified, and at these time points there was no evidence of either nerve degeneration or invasion by tumor cells. At all time points examined, the skin overlying the tumor had normal morphology and was not invaded by tumor cells. Comparison of fibrosarcoma and melanoma tumors on PID 9 revealed that although the fibrosarcoma tumors showed evidence of osteolysis, melanoma tumors did not (Fig. 2). The melanoma tumor was separated from bone matrix by an intact layer of periosteum, and at no point did the bone edge become irregular, thus indicating a lack of bone invasion by the melanoma tumor. Histological examination of the fibrosarcoma and melanoma tumors revealed very little inflammatory cell (neutrophil and lymphocyte) infiltration of the tumor site (tumor, bone, muscle, and surrounding connective tissue). These results corroborate the histological findings of Clohisy et al. (1996) after implantation of these fibrosarcoma cells into the medullary space of the femur.

\section{Tumor-induced behavioral changes}

Behaviorally, there was neither evidence of ongoing pain (guarding of the hindpaw) nor any signs of evoked pain during palpation of the hindpaw in animals receiving either sham injection or melanoma tumor cell injection into the calcaneus bone. In contrast, animals injected with fibrosarcoma cells into the calcaneus showed pronounced curling of the toes, cupping and guarding of the ipsilateral paw, and a distinct preference for weight bearing on the contralateral hindpaw during normal ambulation on a wire mesh surface. Curling of the toes and cupping and guarding of the paw were also evident while the animals were being handled. Furthermore, palpation of the tumor-bearing heel from PID 8 to 12 elicited a withdrawal response.

\section{Fibrosarcoma-induced hyperalgesic behaviors}

Fibrosarcoma implantation into and around the heel of $\mathrm{C} 3 \mathrm{H} / \mathrm{He}$ mice induced hyperalgesia to mechanical and cold stimuli when compared with naive and sham-implanted controls (Fig. 3). Mechanical hyperalgesia was evident in response to stimulation of the hindpaw with a normally non-noxious von Frey monofilament (3.4 mN bending force) (Fig. $3 A$ ) as early as PID 3. In addition, progressive cold hyperalgesia was observed as a significant increase in the number of nocifensive behaviors over a 4 min period on the $2-4^{\circ} \mathrm{C}$ cold plate beginning by PID 10 (Fig. $3 B$ ). Tumor cell implantation into the calcaneus bone produced a greater hypersensitivity with an earlier onset of increased responsiveness (Fig. 3) compared with subcutaneous implantation into the heel not involving the bone, which yielded $34.3 \pm 2.7 \%$ response to mechanical stimuli [area under the curve (AUC), 6-17 PID] and $10.8 \pm 1.3$ nociceptive behaviors on the cold plate (AUC, 7-16 PID).

Tumor size in $\mathrm{C} 3 \mathrm{H} / \mathrm{He}$ mice, measured over the time course as the width of the heel, showed continuous progression with PID 10 measurements of $4.6 \pm 0.2 \mathrm{~mm}$ compared with $3.3 \pm 0.06 \mathrm{~mm}$ for the naive group $(n=10)$. $\mathrm{C} 3 \mathrm{H} / \mathrm{He}$ mice, injected with paraffin wax of size similar to the fibrosarcoma in the heel as a non-tumor mass control, were tested across days 1-7; observed heel width of $4.5 \pm 0.08 \mathrm{~mm}$ was not accompanied by hyperalgesia $(22.3 \pm$ $5.5 \%$ response; $n=5$ ). Behavioral testing was concluded at PID 15 because the incidence of skin lesions in a small number of animals might have confounded sensory testing results. Bone loss was evident at necropsy in mice that exhibited osteolysis, but not in the sham-treated mice or mice with tumors in subcutaneous tissue only (see below).

\section{Fibrosarcoma but not melanoma tumors of similar size induce mechanical hyperalgesia}

Nonosteolytic melanoma tumors of size similar to the fibrosarcoma did not produce hyperalgesia when implanted in the heel of B6C3f1/cr mice. Figure 4 presents the correspondence between increasing tumor/heel size (bars) and hyperalgesia (lines): fibrosarcoma growth was more localized to the heel than was melanoma through day 15 after implantation, and this was accompa- 


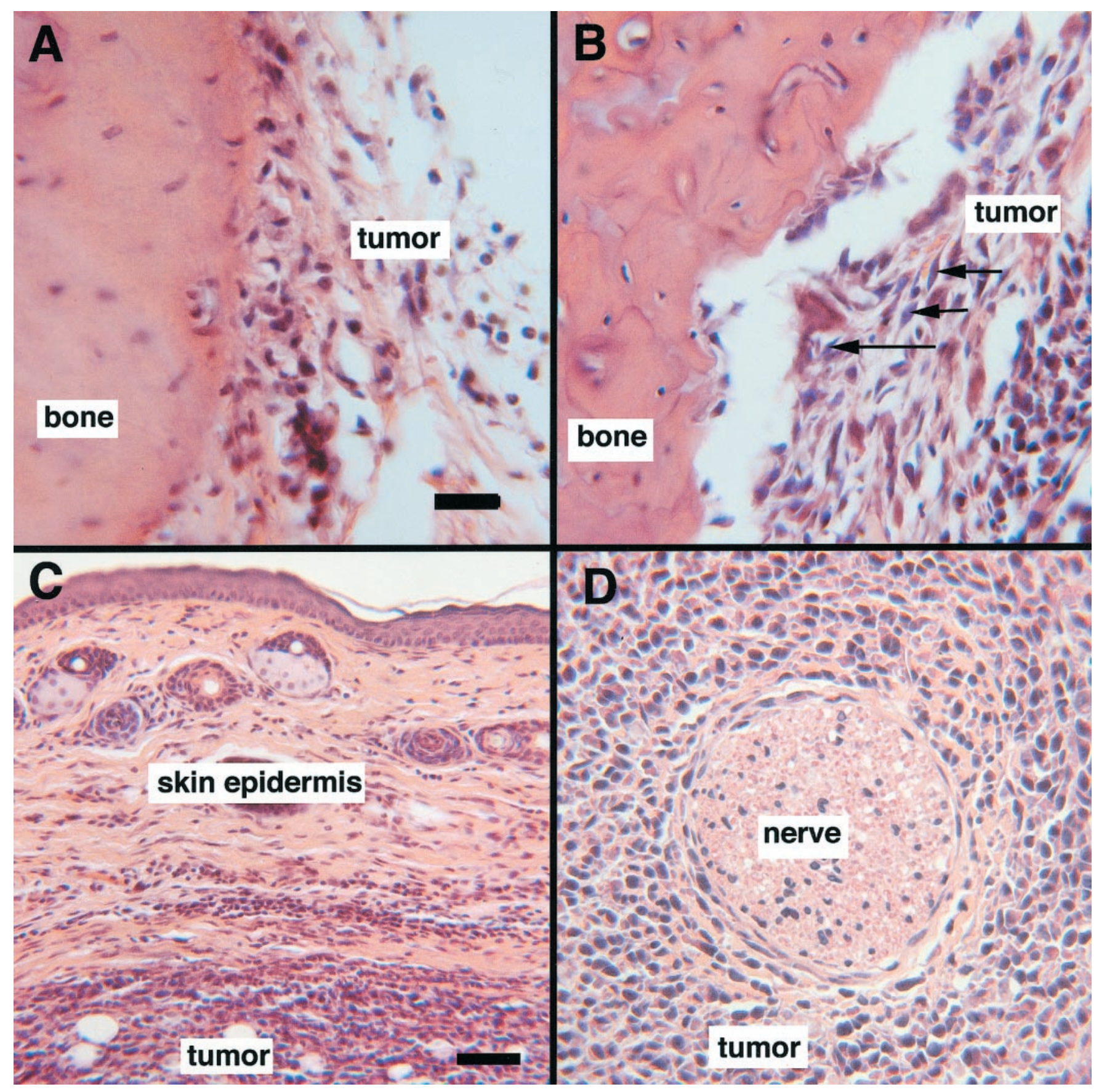

Figure 1. Photomicrographs of hematoxylin and eosin-stained fibrosarcoma tumor sections at different PID time points. $A$, PID 3 fibrosarcoma: tumor cells are closely adhered to bone surface, but the bone edge is intact. B, PID 6 fibrosarcoma: bone edge is irregular, indicative of osteolysis. Arrows indicate individual spindle-shaped fibrosarcoma cells. $C$, Skin overlying tumor at PID 9: note the lack of skin invasion by tumor cells and normal skin morphology. $D$, PID 12 fibrosarcoma: intact nerve bundle surrounded by tumor cells. There is no evidence of nerve invasion by tumor cells or of nerve degeneration at this time point. Scale bars (shown in $A$ ): $A, B, D, 20 \mu \mathrm{m} ; C, 60 \mu \mathrm{m}$.

nied by more intense hyperalgesia in the fibrosarcoma-implanted mice. Postmortem dissection of the tumor-implanted paws showed that the melanoma and fibrosarcoma tumors had equal mass on PID 15 but that fibrosarcoma tumors adhered to and invaded the calcaneus bone and caused its destruction. Dissection and subsequent measurement of the calcaneus bone from the fibrosarcoma-injected heel revealed a significant reduction in calcaneus thickness: $0.7 \pm 0.1$ versus $1.2 \pm 0.03 \mathrm{~mm}$ on the contralateral side compared with $1.1 \pm 0.03 \mathrm{~mm}$ in the melanomabearing heel.

\section{Systemic morphine dose-dependently attenuates mechanical hyperalgesia}

Systemic morphine injected (3-30 mg/kg, i.p) on PID 15 attenuated the fibrosarcoma-induced mechanical hyperalgesia in calcaneus-implanted $\mathrm{C} 3 \mathrm{H} / \mathrm{He}$ mice in a dose-dependent manner with an $\mathrm{ED}_{50}$ of $9.0 \mathrm{mg} / \mathrm{kg}$ (95\% confidence interval, 6.8-11.7) and a maximum inhibition of $87 \%$ at $30 \mathrm{mg} / \mathrm{kg}(n=12)$. In addition, morphine was found to be effective in attenuating tumor-induced cold sensitivity (data not shown). Neither sedation 


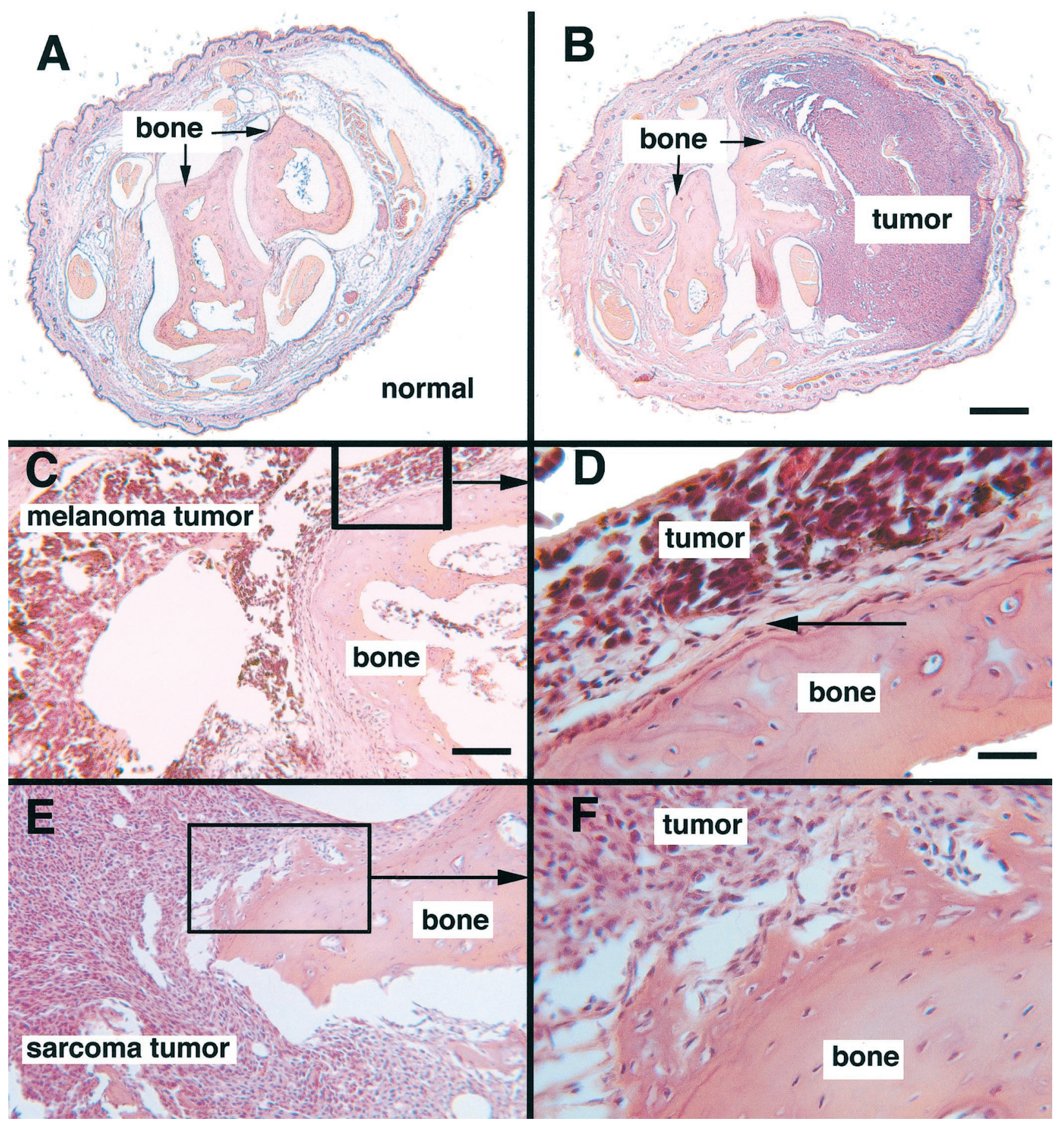

Figure 2. Photomicrographs of hematoxylin and eosin-stained sections of a normal and tumor-bearing mouse heel. $A$, Cross section of normal mouse heel. $B$, Cross section of a comparable area at PID 9 of fibrosarcoma cells. $C-F$, Comparison of fibrosarcoma tumor and control melanoma tumor morphology. $C$, PID 9 melanoma tumor. $D$, Enlargement of boxed area in $C$ : note the regular bone edge and layer of periosteum (arrow) separating bone and tumor cells. $E$, PID 9 fibrosarcoma tumor. $F$, Enlargement of boxed area in $E$ : note irregular bone edge and invasion of tumor cells into bone, indicating osteolysis. Scale bars: (shown in $B) A, B, 500 \mu \mathrm{m}$; (shown in $C$ ) $C, E, 100 \mu \mathrm{m}$; (shown in $D$ ) $D, F, 30 \mu \mathrm{m}$.

nor motor impairment were observed during the post-drug testing period after morphine administration, although some hyperactivity was evident at the high dose $(30 \mathrm{mg} / \mathrm{kg})$. Analgesic attenuation of hyperalgesia without sedation or motor impairment validates this model of hyperalgesia.
Measurement of ET in fibrosarcoma cells and tumors Microbead immunosorbent assay assessment: standard curve In vitro testing of the microprobe indicated that recoveries of ET-1 and BSA were 68 and $62 \%$, respectively, as compared with a microdialysis probe recovery of $4.2 \%$ for ET- 1 and $0 \%$ for BSA. 

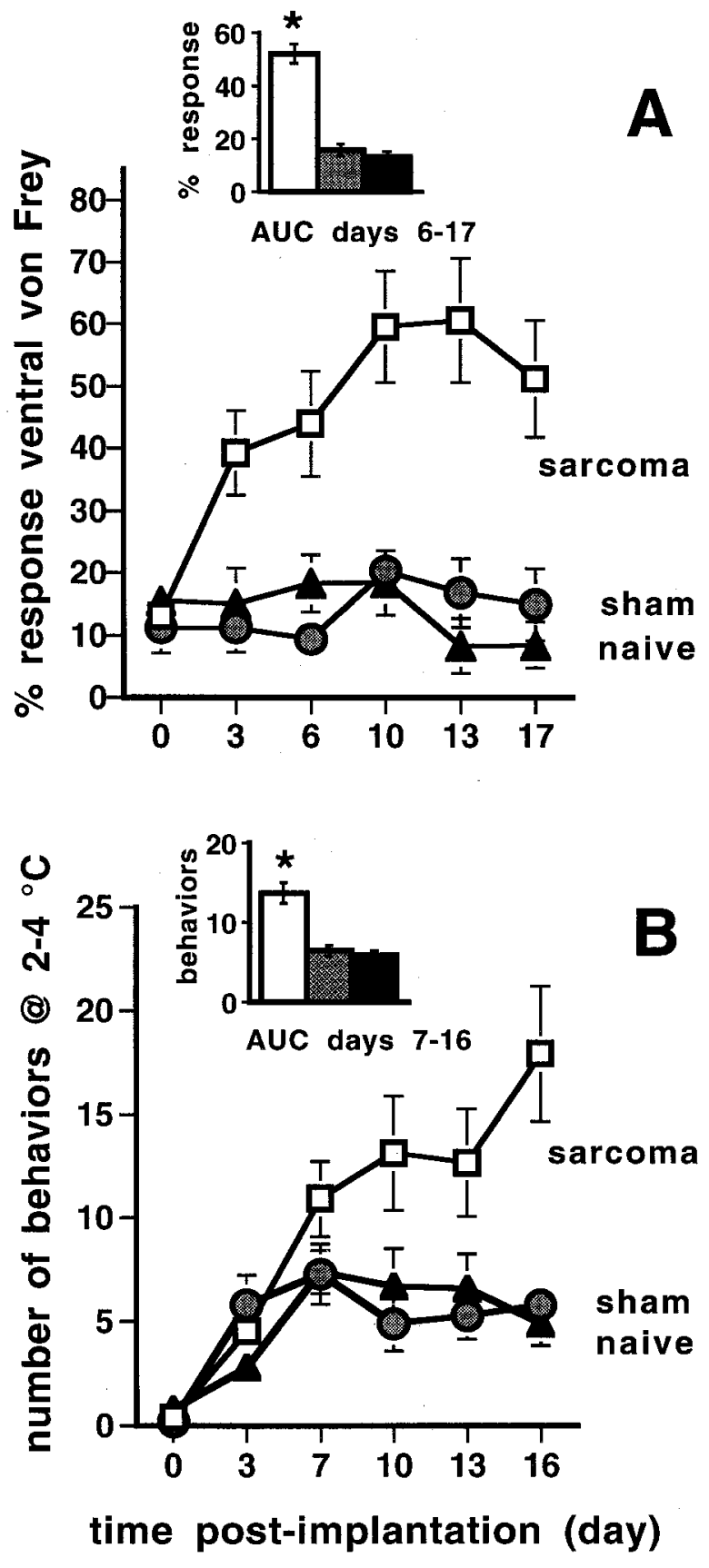

Figure 3. A, Mechanical hyperalgesia after development of the fibrosarcoma tumor. The withdrawal responses evoked by a normally non-noxious von Frey monofilament ( $3.4 \mathrm{mN}$ bending force) increased significantly as early as PID 3 . The percentage response was calculated as the number of positive responses divided by 6 (the total number of stimuli per paw) multiplied by 100 . The mean and SEM were calculated for each group for PID 6-15, and the data were analyzed for significance (*) using ANOVA $(p<0.01)$ with Bonferroni post hoc tests. B. Cold hypersensitivity was detected after the development of the fibrosarcoma tumor and measured as a significant increase in the number of nociceptive behaviors over a 4 min period on a $2-4^{\circ} \mathrm{C}$ cold plate. The mean and SEM were calculated for each group for PID 7-16, and the data were analyzed for significance using ANOVA ( $*$ indicates significance; $p<0.01$ ) with Bonferroni post hoc tests ( $n=14$ tumor; $n=9$ sham; $n=10$ naive).

Similar in vitro microperfusion recovery rates were found when testing NGF and TNF $\alpha$ (data not shown). Labeling of known amounts of ET adsorbed to beads with antibody and analysis by

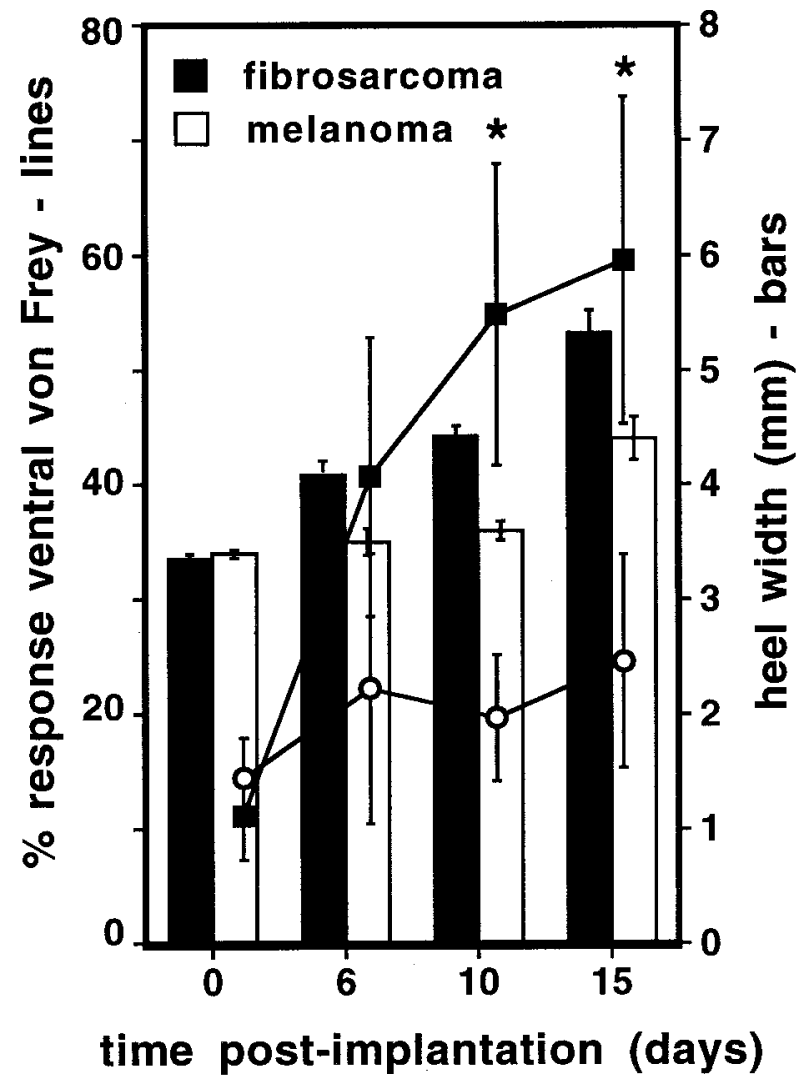

Figure 4. B6C3f1/cr mice implanted with fibrosarcoma cells, but not melanoma or saline (sham, data not shown), showed significant mechanical hyperalgesia in response to plantar stimulation with a normally non-noxious $1.6 \mathrm{mN}$ von Frey monofilament. Lines (left axis) show increasing hyperalgesia as the fibrosarcoma tumor grew, with greater hyperalgesia evident on PID 10 and 15 than both the melanoma-implanted and sham mice (data not shown). Bars (right axis) show the corresponding progression of heel width for both fibrosarcoma and melanoma as measured on PID 1-15 (PID 1-5 not shown) with a micrometer; note that the two tumor types had equivalent size at PID 15 (melanoma, $4.4 \mathrm{~mm} \pm$ $0.19)$ and PID 10 (fibrosarcoma, $4.43 \mathrm{~mm} \pm 0.20)(n \geq 7)$. The mean and SEM are shown for each experimental group. Fibrosarcoma tumor, melanoma tumor, and sham groups were compared by ANOVA followed by a Fisher's post hoc test where * indicates significant differences from control $(p<0.05)$.

flow cytometry indicated that MFI increases linearly with the concentration of ET-1.

Fibrosarcoma tumor homogenates contain increased levels of ET

MBISA of homogenates of whole tumors on PID 5, 7, 10, and 12 (Fig. 5) showed that ET MFI was increased on PID 7, 10, and 12 $(19.7 \pm 0.9,26.7 \pm 4.7$, and $17.6 \pm 5.2)$ compared with control MFI from the contralateral paw at PID $5(5.6 \pm 0.35)$. The inset in Figure 5 shows representative flow cytometry histograms for naive and tumor-implanted mice at PID 7, 10, and 12. The production of ET by the fibrosarcoma tumor increased by PID 7 and peaked around PID 10.

Fibrosarcoma tumor microperfusates contain increased levels of ET

In vivo microperfusion of fibrosarcoma tumors in awake, freely moving mice between PID 8 and 13 evaluated the time course of ET release into the extracellular fluid of the tumor site (Fig. 6). 


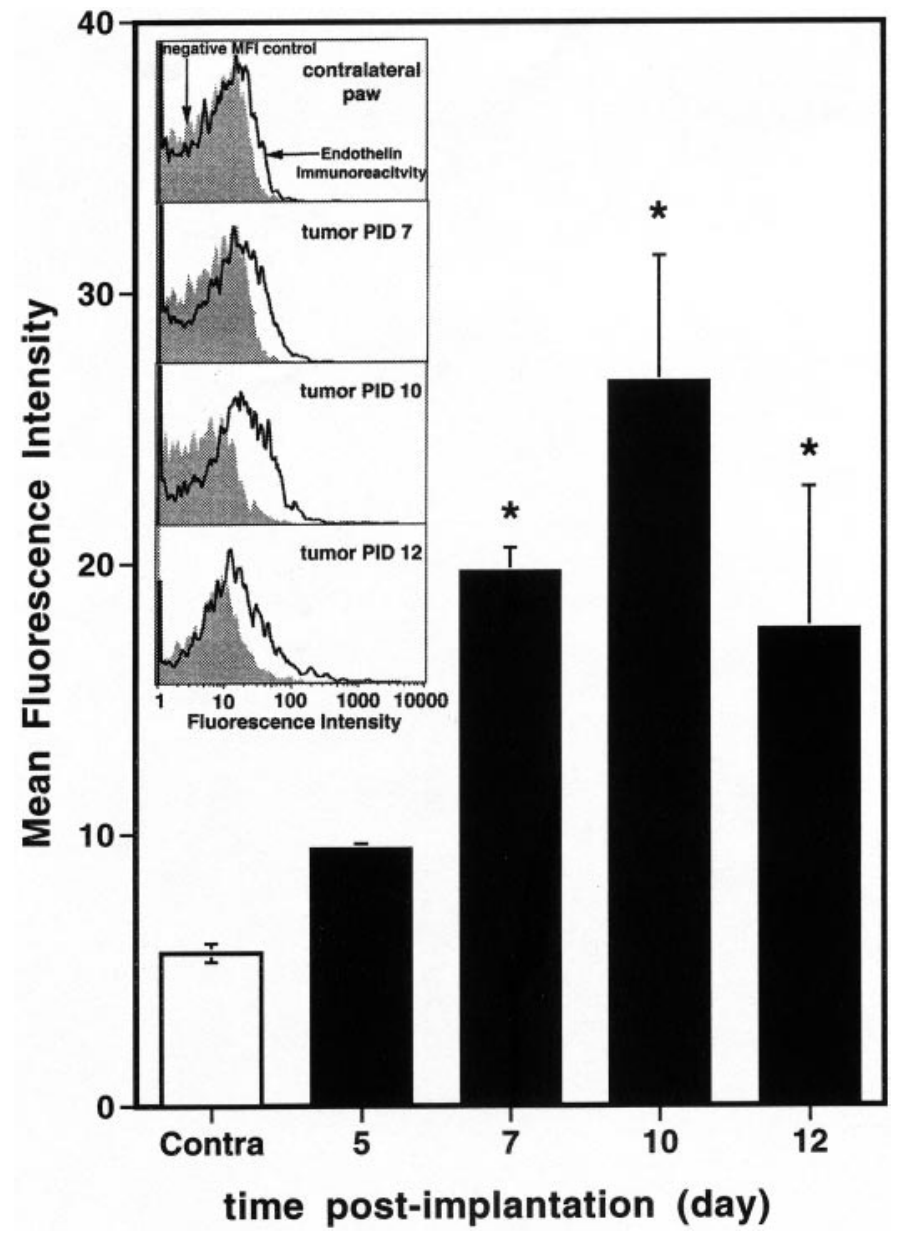

Figure 5. Homogenates of harvested tumors contain increased levels of ET on PID 7, 10, and 12 as compared with homogenates from the contralateral limb. Tumors were harvested and homogenized; the supernatant was analyzed by flow cytometry for ET. Group size is four to five mice at each time point; ${ }^{*} p<0.05$. Inset indicates representative flow cytometry histograms from tumor homogenates analyzed by MBISA. Tumor homogenate proteins were adsorbed to $4 \mu \mathrm{m}$ latex microbeads, and the beads were labeled with anti-ET antisera (open histograms). Nonspecific antibody labeling was determined using negative control NRS (negative MFI control, filled histograms). Bead staining was assessed by flow cytometry and from these data; the MFI was calculated from the histograms and subjected to statistical analyses.

MBISA of the perfusates showed that ET MFI increased on PID 9, 10, and $11(39.7 \pm 6.1,41.9 \pm 4.7$, and 53.0 \pm 8.4 compared with naive mice, $20.8 \pm 7.1$ ). Replication of this experiment in B6C3fe/1 mice and comparison of mice with fibrosarcoma and melanoma tumors yielded consistent results: MBISA showed higher ET MFI in mice with fibrosarcoma tumors compared with mice implanted with melanoma tumors or compared with naive controls (57.9 \pm 9.2 vs $28.3 \pm 5.9$ and $23.2 \pm 8.1$, respectively) (Fig. 7). As indicated in Materials and Methods, the ET antibody used recognizes all three forms of ET; absence of increased ET-3-immunoreactivity in the fibrosarcoma microperfusates (data not shown) suggests that the tumor releases either ET-1 or ET-2.

\section{In vitro microperfusion}

MBISA on media conditioned for $24 \mathrm{hr}$ with fibrosarcoma cells yielded higher ET MFI than did MBISA of melanomaconditioned and cell-free control media (50.1 \pm 8.3 compared

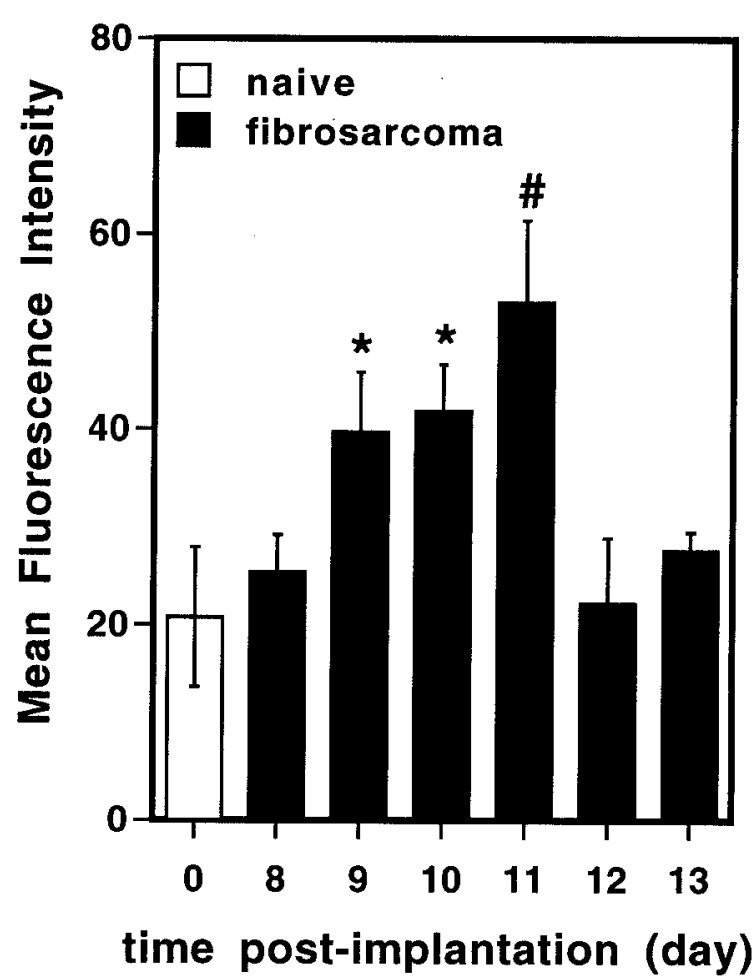

Figure 6. Fibrosarcoma tumors secrete increased levels of ET on PID 9, 10, and 11. Extracellular fluid from fibrosarcoma tumor sites was sampled by microperfusion on PID 8-13 and compared with microperfusates from the hindlimb of naive mice. The relative level of ET was determined by flow cytometry. Group size is four to six mice per time point; * indicates $p<0.05$ compared with naive; \# indicates $p<0.01$ compared with naive.

with $6.3 \pm 1.2$ for melanoma-conditioned and $11.2 \pm 3.0$ for cell-free control media; $p<0.0005$ ) (Fig. 7). This result demonstrates that the fibrosarcoma cell line, but not the melanoma cell line, produces and secretes ET, indicating that the fibrosarcoma cells contribute to the release of the ET measured in tumor homogenates and tumor microperfusates.

\section{Algogenic activity of ET-1}

Injection of ET-1 (4.0 pmol-1.2 nmol/30 $\mu \mathrm{l})$ into the ipsilateral hindpaw of mice bearing fibrosarcoma tumors at PID 10 (when ET perfusate yield peaked) produced dose-related licking of and attending to the injected paw for $10 \mathrm{~min}$ when compared with vehicle-injected and naive controls (Fig. 8). This experiment shows that tumor-bearing mice manifest higher sensitivity to ET-1 than naive mice, supporting a local pronociceptive action of ET-1.

\section{Cycloheximide injected into the tumor site attenuates} mechanical hyperalgesia

Injection of the protein synthesis inhibitor cycloheximide $(150 \mu \mathrm{g}$ in $10 \mu \mathrm{PBS}$ ) into the calcaneus tumor site of hyperalgesic mice (PID $8 ; n=5$ ) attenuated responses to $40 \pm 9.2 \%$ relative to preinjection baseline $(82 \pm 4.6 \%)$ more than PBS sham injection (67 $\pm 8.8 \%$ response) between 4 and $12 \mathrm{hr}$ after injection.

ET-A receptor antagonist $B Q-123$ attenuates ET-1- and tumor-induced hyperalgesia

Intraplantar injection of the ET-A receptor antagonist BQ-123 $(1.6$ or $16 \mathrm{nmol} / 30 \mu \mathrm{l}$ ) in naive $\mathrm{C} 3 \mathrm{H} / \mathrm{He}$ mice before ET-1 (400 $\mathrm{pmol} / 30 \mu \mathrm{l})$ injection reduced the time spent licking to control 


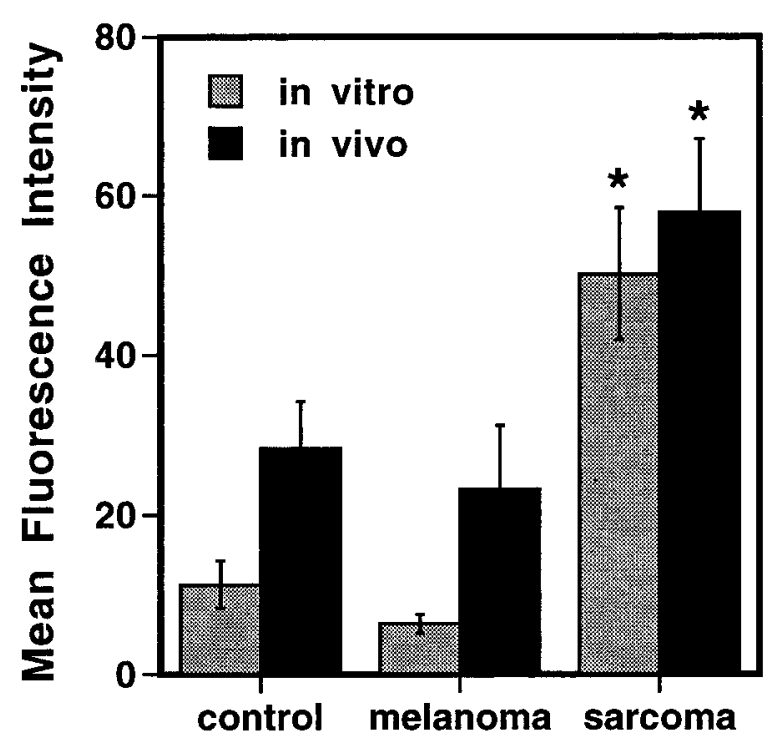

Figure 7. Fibrosarcoma cells in vitro (gray bars) and in vivo (black bars) secrete more ET than melanoma cells. Serum-free medium incubated with tumor cells for $24 \mathrm{hr}$ was analyzed in triplicate for the presence of ET by flow cytometry. Levels in conditioned media were compared with those in cell-free media (control). For in vivo analysis, mice implanted with fibrosarcoma or melanoma tumors and naive mice (control) underwent microperfusion on PID 8. The relative levels of ET were determined by flow cytometry. Group size is three to four mice per condition at each time point; $*$ indicates $p<0.05$ compared with control and melanoma samples.

levels. Pretreatment with saline or the ET-B receptor antagonist BQ-788 $(0.1,1.0$, and $10 \mathrm{nmol} / 30 \mu \mathrm{l})$ was without effect. Intraplantar injection of BQ-123 (16 nmol) had no effect on nociceptive mechanical sensitivity (von Frey monofilament, $12.1 \mathrm{mN}$ bending force) in naive mice ( $n=7$; data not shown).

To test for ET receptor participation in tumor-induced hyperalgesia, BQ-123 (0.16-16 nmol/30 $\mu \mathrm{l})$, BQ-788 (0.16-48 nmol/30 $\mu \mathrm{l})$, or saline $(30 \mu \mathrm{l})$ was injected into the tumor site of PID 10-12 fibrosarcoma-implanted $\mathrm{C} 3 \mathrm{H} / \mathrm{He}$ mice showing $>60 \%$ responsiveness to von Frey stimulation $(3.4 \mathrm{mN})$. Preliminary experiments had resolved the time course of BQ-123 effects (peak $45 \mathrm{~min}$, duration until $180 \mathrm{~min}$ after injection). Figure 9 shows that BQ-123 reduced hyperalgesia 45 min after injection, reaching a maximum inhibition of $43 \pm 11.6 \%$ at $1.6 \mathrm{nmol}$. BQ-788 was inactive at doses below $16 \mathrm{nmol}$ as was saline, but $16 \mathrm{nmol}$ of BQ-788 reduced hyperalgesia slightly $(15 \pm 11.6 \%)$. Systemic (intraperitoneal) administration of BQ-123 (16-48 nmol/30 $\mu \mathrm{l})$ in tumor-bearing mice was inactive at any time point tested. These results suggest that ET-1 contributes to the mechanical hyperalgesia in tumor-bearing mice by activating ET-A receptors.

\section{DISCUSSION}

The present paper, together with its companion paper (Cain et al., 2001b), defines a new model of cancer pain in which an osteolytic tumor grows locally in and around the calcaneus bone of the mouse hindpaw. Together, these two studies define the histological, behavioral, neurochemical, neuroanatomical, and neurophysiological characteristics of the tumor model. The model is distinguished by the presence of spontaneously active and hyper-responsive $\mathrm{C}$-fibers and the development of morphinesensitive mechanical and cold hyperalgesia. The tumor-induced nociception appears to result from the release of algogenic mediators, the participation of one of which, endothelin, is docu-

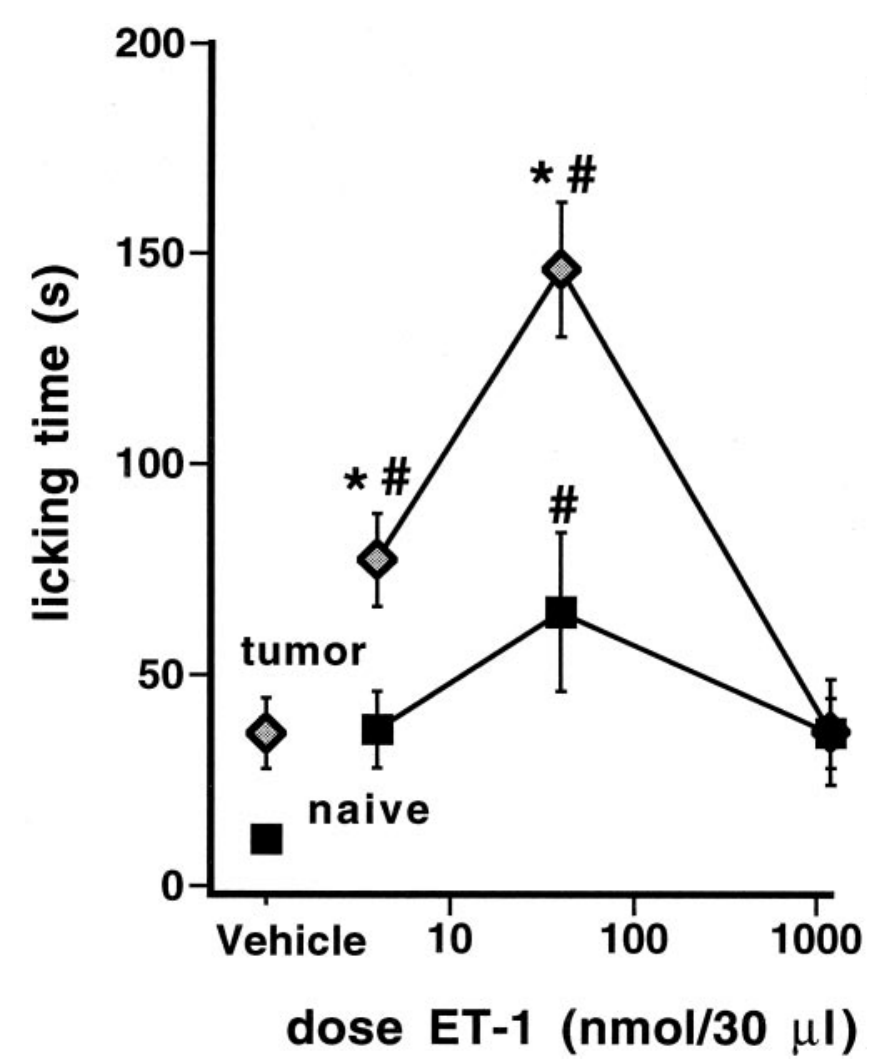

Figure 8. The duration of nocifensive behaviors in seconds ( $s$ ) was accumulated over a $10 \mathrm{~min}$ period after ET-1 (4.0 pmol-1.2 nmol/30 $\mu \mathrm{l})$ or saline $(30 \mu \mathrm{l})$ injection into the fibrosarcoma tumor site of $\mathrm{C} 3 \mathrm{H} / \mathrm{He}$ mice at PID 10 or into the heel of naive mice. Data are presented as mean and SEM, analyzed by ANOVA, and further tested for differences from respective saline-sham control $(*)$ and between-treatment groups (\#) with the Fisher's post hoc test; * and \# indicate statistical significance; $p<$ $0.05(\mathrm{n} \geq 10)$.

mented in this paper. The joint conclusion of these two papers is that early hyperalgesia appears to be tumor induced and nociceptive in nature, but that neuropathic components may develop later in the course of the growth of the tumors.

Beyond assertions of tumor infiltration around bone or nerve and the utility of morphine in treating cancer pain, a lack of knowledge surrounds the mechanistic basis of cancer pain, primarily because animal models have only recently been described in mouse femur (Schwei et al., 1999; Wacnik et al., 2000) and humerus (Wacnik et al., 2000). These initial models are limited by the difficulty of electrophysiological and neurochemical evaluation of deep peripheral hyperalgesia. The hindpaw, by contrast, is a standard site for the development and study of many acute and chronic pain models in mice (Mansikka et al., 1999; Mogil et al., 1999; Fairbanks et al., 2000) and rats (Stein et al., 1988; Schadrack et al., 1999; Jinks and Carstens, 2000; Du et al., 2001; Zheng and Chen, 2001) because it provides ready access for testing primary and secondary hyperalgesia and allows for electrophysiological recording (Cain et al., 2001a,b), local drug delivery, and fluid collection. This new tumor pain model applies fibrosarcoma cells into and around the hindpaw calcaneus bone to mimic the painful condition observed in human calcaneus bone cancer (Sarlak et al., 2000) and characterizes behavioral, morphological, neurochemical, and algogenic sequelae. The companion paper (Cain et al., 2001b) characterizes electrophysiological and neuroanatomical sequelae to tumor growth. 


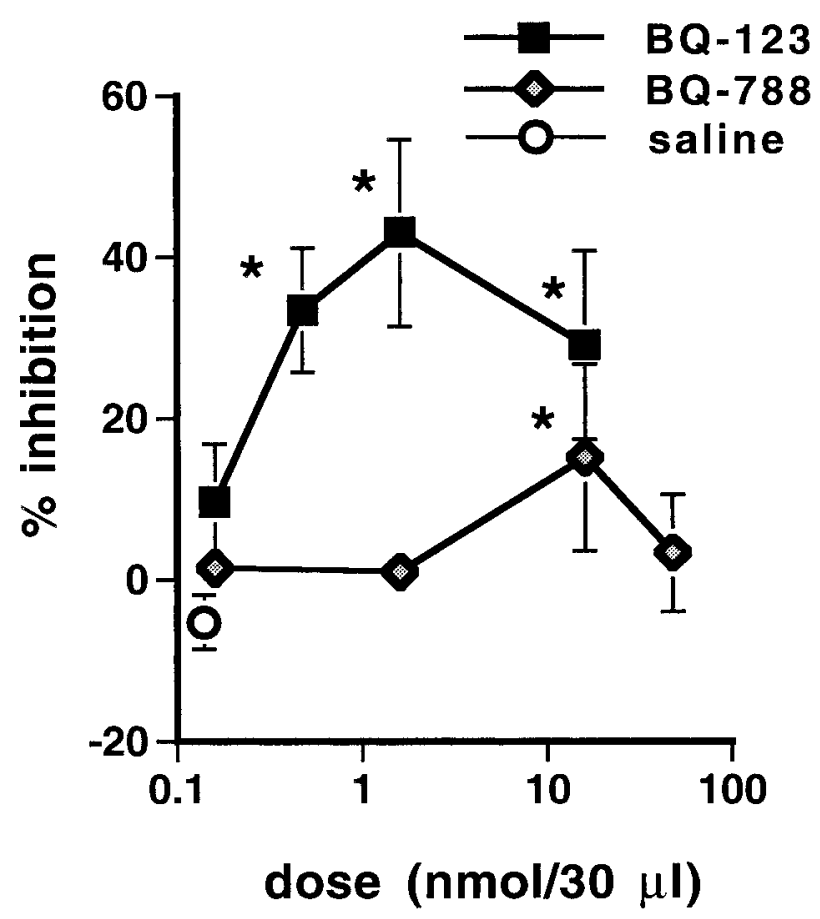

Figure 9. The ET-A receptor antagonist BQ-123 $(0.16-16 \mathrm{nmol} / 30 \mu \mathrm{l})$ injected into the tumor site of hyperalgesic $\mathrm{C} 3 \mathrm{H} / \mathrm{He}$ mice with fibrosarcoma tumors on PID 10 produced dose-dependent attenuation of mechanical hyperalgesia (45 min post-drug; $n \geq 9$; filled squares). Injection of the ET-B receptor antagonist BQ-788 $(0.16-48 \mathrm{nmol} / 30 \mu \mathrm{l})$ on PID 12 attenuated mechanical hyperalgesia only at the highest dose tested (45 min post-drug; $n \geq 9$; shaded diamonds). Saline, similarly injected into the tumor site of PID 10 and 12 hyperalgesic $\mathrm{C} 3 \mathrm{H} / \mathrm{He}$ mice, was inactive $(n=$ 20; open circles). Data are presented as mean and SEM, analyzed by ANOVA, and further tested for differences from saline-vehicle control (*) with the Fisher's post hoc test; * indicates statistical significance; $p<$ 0.05 .

The NCTC 2472 fibrosarcoma cell line activates osteoclasts and promotes bone destruction when injected into the medullary cavity (Clohisy et al., 1996), and tumors resulting from implantation of cells in the femur produce spontaneous pain behavior (Schwei et al., 1999; Honore et al., 2000a) and secondary cutaneous hyperalgesia (Wacnik et al., 2000; Honore et al., 2000b). The present study shows that calcaneus implantation involves both bone and soft tissue, enhances responses to mechanical and cold stimuli at the tumor site, and elicits spontaneous nociceptive behaviors (favoring, cupping, and guarding the affected paw) reminiscent of cancer pain symptoms involving the tibia or calcaneus (Caraceni and Portenoy, 1999; Sarlak et al., 2000; De Geeter et al., 2001).

Honore and colleagues (Honore et al., 2000b) infer from indirect CNS indicators a character of tumor-induced nociception different from that of inflammatory or neuropathic nociception, suggesting different peripheral mechanisms. Consistent with this inference, histological analysis of the tumor site in the calcaneus model showed no evidence of neuropathy (lack of axonal swelling and overt pathology) or inflammation (absence of numerous lymphocytes and neutrophils), suggesting that the observed hyperalgesia up to PID 12 is neither inflammatory nor neuropathic. Moreover, the antinociceptive efficacy of ET-A but not ET-B receptor antagonists is also consistent with a noninflammatory origin for nociception (Griswold et al., 2000). The efficacy of cycloheximide in reducing hyperalgesia argues against nerve compression by the tumor as the sole basis for the nociception associated with this model but is consistent with release of peptidergic algogens from the tumor or surrounding tissue, further suggesting that the nociception may be somatic in nature. However, the microenvironment of injured nerves may also contain some inflammatory mediators (Zochodne, 2000), so that the presence of peptidergic algogens alone would not be inconsistent with a neuropathic basis for the observed nociception. However, neither the histological nor the behavioral data obtained from paraffin- or melanoma-injected control animals support nerve compression as a neuropathic cause for the nociception associated with this model. Collectively these data indicate that the nociception observed in this model from PID 6 to PID 12 does not result from inflammation or nerve compression, but rather involves the release of peptidergic mediators such as ET. Nerve injury, however, was identified histologically and functionally in later stages of tumor development (Cain et al., 2001b).

The present study demonstrates that ET is released from tumor cells in vitro and from the tumor site in vivo; apparently this released ET is capable of enhancing the nociceptive effects of exogenous ET-1 injected into the tumor site. These data, together with the antinociceptive effect of the $\mathrm{ET}_{\mathrm{A}}$ receptor antagonist in tumor-injected mice, argue that tumor-derived ET plays a nociceptive role in this hindpaw tumor model. Previous evidence documents the nociceptive effects of ET-1 (Raffa et al., 1996; De-Melo et al., 1998): exogenous ET-1 produces behavioral signs of acute pain (Davar et al., 1998), contributes to neuropathic tactile allodynia (Jarvis et al., 2000), and enhances inflammatory pain (Piovezan et al., 1997; De-Melo et al., 1998). Furthermore, the present study provides the first evidence that ET-1 likely contributes to nociceptive transmission from fibrosarcoma tumors to sensory nerves. In rats, whereas $\mathrm{ET}_{\mathrm{A}}$ receptors are colocalized with CGRP in both DRG and sciatic nerve, $\mathrm{ET}_{\mathrm{B}} \mathrm{Rs}$ are colocalized with GFAP, presumably in glia (Pomonis et al., 2001). Evidence that ET-1 may be a modulator of sensory neuronal function was shown by Dymshitz and Vasko (1994): capsaicininduced substance P and CGRP release was augmented (50\%) after pretreatment with ET-1 in rat sensory neuron cultures. Melanoma tumors did not release ET and did not produce hyperalgesia, suggesting that the tumor itself is the major source of the released ET. This result is important because ET is produced by several types of tumor that produce pain in patients (Asham et al., 1998; Kurbel et al., 1999). Although all three ET isopeptides are active in behavioral nociceptive assays (Raffa and Jacoby, 1991; Piovezan et al., 1997), ET-3 is not released by the fibrosarcoma tumor and is not nociceptive in mice; therefore, ET-1 and ET-2 are the likely candidate algogens in this model. In view of the observations that $\mathrm{ET}_{\mathrm{A}}$, but not $\mathrm{ET}_{\mathrm{B}}$, receptors are present in a subset of primary afferent fibers (Pomonis et al., 2001) and mediate ET-1-induced nociceptive behaviors and enhancement of capsaicin-induced nociception in mice (Piovezan et al., 2000), the ET released from the sarcoma likely acts on $\mathrm{ET}_{\mathrm{A}}$ receptors to induce nociception in this model.

\section{Analgesics and cancer pain}

Opioids remain the key treatment for chronic cancer pain (Portenoy, 2000). Morphine attenuation of hyperalgesia seen in this hindpaw model both confirms its usefulness as a model of cancer pain and indicates its susceptibility to opioids. Furthermore, it is notable that the systemic potency of morphine in this chronic tumor pain model $\left(\mathrm{ED}_{50} \sim 10 \mathrm{mg} / \mathrm{kg}\right)$ is comparable to its potency in this mouse strain using common acute thermal nociceptive tests $\left(\mathrm{ED}_{50} 3-15 \mathrm{mg} / \mathrm{kg}\right)$ and lower than its potency in tonic 
chemical nociceptive tests $\left(\mathrm{ED}_{50} \leq 1 \mathrm{mg} / \mathrm{kg}\right)$ (Jacob et al., 1983; Elmer et al., 1998). This relatively low potency echoes the low potency observed in clinical cancer pain therapy (Portenoy, 2000). In the femur tumor model in which NCTC 2472 cells are injected into the medullary cavity (Clohisy et al., 1996), morphine attenuates the secondary mechanical hyperalgesia (measured on the plantar surface of the ipsilateral hindpaw) with similar potency and efficacy (Honore et al., 2000b; Wacnik et al., 2000). In contrast, implantation of fibrosarcoma cells bilaterally into the humeri induces a movement-related hyperalgesia that is only partially attenuated by morphine (P. W. Wacnik, L. J. Kehl, and G. L. Wilcox, unpublished observations). The combined application of these models will undoubtedly be useful for further characterizing the effectiveness of opiate analgesics in cancer pain but more importantly for the development of other nonopiate analgesics, such as ET receptor antagonists, based on novel mechanistic knowledge of cancer pain gained through the application of these and future animal models.

\section{REFERENCES}

Asham EH, Loizidou M, Taylor I (1998) Endothelin-1 and tumour development. Eur J Surg Oncol 24:57-60.

Banning A, Sjogren P, Henriksen H (1991) Treatment outcome in a multidisciplinary cancer pain clinic. Pain 47:129-134.

Cain DM, Khasabov SG, Simone DA(2001a) Response properties of mechanoreceptors and nociceptors in mouse glabrous skin: an in vivo study. J Neurophysiol 85:1561-1574.

Cain DM, Wacnik PW, Turner M, Wendelschafer-Crabb G, Kennedy WR, Wilcox GL, Simone DA (2001b) Functional interactions between tumor and peripheral nerve: changes in excitability and morphology of primary afferent fibers in a murine model of cancer pain. J Neurosci 21:9367-9376.

Caraceni A, Portenoy RK (1999) An international survey of cancer pain characteristics and syndromes. IASP Task Force on Cancer Pain. International Association for the Study of Pain. Pain 82:263-274.

Chirgwin JM, Guise TA (2000) Molecular mechanisms of tumor-bone interactions in osteolytic metastases. Crit Rev Eukaryot Gene Expr 10:159-178.

Clohisy DR, Ogilvie CM, Carpenter RJ, Ramnaraine ML (1996) Localized, tumor-associated osteolysis involves the recruitment and activation of osteoclasts. J Orthop Res 14:2-6.

Curtsinger J, Deeths MJ, Pease P, Mescher MF (1997) Artificial cell surface constructs for studying receptor-ligand contributions to lymphocyte activation. J Immunol Methods 209:47-57.

Davar G, Hans G, Fareed MU, Sinnott C, Strichartz G (1998) Behavioral signs of acute pain produced by application of endothelin-1 to rat sciatic nerve. NeuroReport 9:2279-2283.

De Geeter K, Reynders P, Samson I, Broos PL (2001) Metastatic fractures of the tibia. Acta Orthop Belg 67:54-59.

De-Melo JD, Tonussi CR, D’Orleans-Juste P, Rae GA (1998) Articular nociception induced by endothelin-1, carrageenan and LPS in naive and previously inflamed knee-joints in the rat: inhibition by endothelin receptor antagonists. Pain 77:261-269.

Du JH, Koltzenburg M, Carlton SM (2001) Glutamate-induced excitation and sensitization of nociceptors in rat glabrous skin. Pain 89:187-198.

Dymshitz J, Vasko MR (1994) Endothelin-1 enhances capsaicin-induced peptide release and cGMP accumulation in cultures of rat sensory neurons. Neurosci Lett 167:128-132.

Elmer GI, Pieper JO, Negus SS, Woods JH (1998) Genetic variance in nociception and its relationship to the potency of morphine-induced analgesia in thermal and chemical tests. Pain 75:129-140.

Fairbanks CA, Schreiber KL, Brewer KL, Yu CG, Stone LS, Kitto KF, Nguyen HO, Grocholski BM, Shoeman DW, Kehl LJ, Regunathan S, Reis DJ, Yezierski RP, Wilcox GL (2000) Agmatine reverses pain induced by inflammation, neuropathy, and spinal cord injury. Proc Natl Acad Sci USA 97:10584-10589.

Fareed MU, Hans GH, Atanda A, Strichartz GR, Davar G (2000) Pharnmacological characterization of acute pain behavior produced by the application of endothelin-1 to the rat sciatic nerve. J Pain 1:46-53.

Ferreira SH, Romitelli M, de Nucci G (1989) Endothelin-1 participation in overt and inflammatory pain. J Cardiovasc Pharmacol 13:S220-222.

Gandhi CR, Berkowitz DE, Watkins WD (1994) Endothelins. Biochemistry and pathophysiologic actions. Anesthesiology 80:892-905.
Griswold DE, Douglas SA, Martin LD, Davis TG, Davis L, Ao Z Luttmann MA, Pullen M, Nambi P, Hay DW, Ohlstein EH (2000) Targeted disruption of the endothelin-B-receptor gene attenuates inflammatory nociception and cutaneous inflammation in mice. J Cardiovasc Pharmacol 36:S78-81.

Hall TC (1997) Paraneoplastic syndromes: mechanisms. Semin Oncol $24: 269-276$

Honore P, Luger NM, Sabino MA, Schwei MJ, Rogers SD, Mach DB, O'Keefe PF, Ramnaraine ML, Clohisy DR, Mantyh PW (2000a) Osteoprotegerin blocks bone cancer-induced skeletal destruction, skeletal pain and pain-related neurochemical reorganization of the spinal cord. Nat Med 6:521-528.

Honore P, Rogers SD, Schwei MJ, Salak-Johnson JL, Luger NM, Sabino MC, Clohisy DR, Mantyh PW (2000b) Murine models of inflammatory, neuropathic and cancer pain each generates a unique set of neurochemical changes in the spinal cord and sensory neurons. Neuroscience 98:585-598.

Jacob J, Michaud G, Nicola MA, Prudhomme N (1983) Genetic differences in opioids binding sites and in antinociceptive activities of morphine and ethylketocyclazocine. Life Sci 33:645-648.

Jarvis MF, Wessale JL, Zhu CZ, Lynch JJ, Dayton BD, Calzadilla SV, Padley RJ, Opgenorth TJ, Kowaluk EA (2000) ABT-627, an endothelin ET(A) receptor-selective antagonist, attenuates tactile allodynia in a diabetic rat model of neuropathic pain. Eur J Pharmacol 388:29-35.

Jasmin L, Kohan L, Franssen M, Janni G, Goff JR (1998) The cold plate as a test of nociceptive behaviors: description and application to the study of chronic neuropathic and inflammatory pain models. Pain 75:367-382.

Jinks SL, Carstens E (2000) Superficial dorsal horn neurons identified by intracutaneous histamine: chemonociceptive responses and modulation by morphine. J Neurophysiol 84:616-627.

Kurbel S, Kurbel B, Kovacic D, Sulava D, Krajina Z, Dmitrovic B, Sokcevic M (1999) Endothelin-secreting tumors and the idea of the pseudoectopic hormone secretion in tumors. Med Hypotheses 52:329-333.

Mansikka H, Shiotani M, Winchurch R, Raja SN (1999) Neurokinin-1 receptors are involved in behavioral responses to high-intensity heat stimuli and capsaicin-induced hyperalgesia in mice. Anesthesiology 90:1643-1649.

Mercadante S (1997) Malignant bone pain: pathophysiology and treatment. Pain 69:1-18.

Mogil JS, Wilson SG, Bon K, Lee SE, Chung K, Raber P, Pieper JO, Hain HS, Belknap JK, Hubert L, Elmer GI, Chung JM, Devor M (1999) Heritability of nociception I: responses of 11 inbred mouse strains on 12 measures of nociception. Pain 80:67-82

Patterson SL, Sluka KA, Arnold MA (2001) A novel transverse pushpull microprobe: in vitro characterization and in vivo demonstration of the enzymatic production of adenosine in the spinal cord dorsal horn. J Neurochem 76:234-246.

Piovezan AP, D'Orleans-Juste P, Tonussi CR, Rae GA (1997) Endothelins potentiate formalin-induced nociception and paw edema in mice. Can J Physiol Pharmacol 75:596-600.

Piovezan AP, D'Orleans-Juste P, Tonussi CR, Rae GA (1998) Effects of endothelin-1 on capsaicin-induced nociception in mice. Eur J Pharmacol 351:15-22.

Piovezan AP, D'Orleans-Juste P, Souza GE, Rae GA (2000) Endothelin-1-induced ET(A) receptor-mediated nociception, hyperalgesia and oedema in the mouse hind-paw: modulation by simultaneous ET(B) receptor activation. Br J Pharmacol 129:961-968.

Pomonis JD, Rogers SD, Peters CM, Ghilardi JR, Mantyh PW (2001) Expression and localization of endothelin receptors: implications for the involvement of peripheral glia in nociception. $\mathrm{J}$ Neurosci 21:999-1006

Portenoy RK (2000) Current pharmacotherapy of chronic pain. J Pain Symptom Manage 19:S16-20.

Raffa RB, Jacoby HI (1991) Endothelin-1, -2 and -3 directly and bigendothelin-1 indirectly elicit an abdominal constriction response in mice. Life Sci 48:L85-90.

Raffa RB, Schupsky JJ, Jacoby HI (1996) Endothelin-induced nociception in mice: mediation by ETA and ETB receptors. J Pharmacol Exp Ther 276:647-651.

Reale C, Turkiewicz AM, Reale CA (2001) Antalgic treatment of pain associated with bone metastases. Crit Rev Oncol Hematol 37:1-11.

Renno WM, Mullet MA, Williams FG, Beitz AJ (1998) Construction of $1 \mathrm{~mm}$ microdialysis probe for amino acids dialysis in rats. $\mathrm{J}$ Neurosci Methods 79:217-228.

Rubanyi GM, Polokoff MA (1994) Endothelins: molecular biology, biochemistry, pharmacology, physiology, and pathophysiology. Pharmacol Rev 46:325-415.

Sarlak A, Gundes H, Ozkurkcugil C, Ozkara S, Gokalp A (2000) Solitary calcaneal metastasis in superficial bladder carcinoma. Int $\mathrm{J}$ Clin Pract 54:681-682.

Schadrack J, Neto FL, Ableitner A, Castro-Lopes JM, Willoch F, Bar- 
tenstein P, Zieglgansberger W, Tolle TR (1999) Metabolic activity changes in the rat spinal cord during adjuvant monoarthritis. Neuroscience 94:595-605.

Schwei MJ, Honore P, Rogers SD, Salak-Johnson JL, Finke MP, Ramnaraine ML, Clohisy DR, Mantyh PW (1999) Neurochemical and cellular reorganization of the spinal cord in a murine model of bone cancer pain. J Neurosci 19:10886-10897.

Stackpole CW, Alterman AL, Fornabaio DM (1985) Growth characteristics of clonal cell populations constituting a B16 melanoma metastasis model system. Invasion Metastasis 5:125-143.

Stein C, Millan MJ, Herz A (1988) Unilateral inflammation of the hindpaw in rats as a model of prolonged noxious stimulation: alterations in behavior and nociceptive thresholds. Pharmacol Biochem Behav 31: $445-451$.
Tallarida R, Murray R(1987) Manual of pharmacological calculations with computer programs. New York: Springer.

Wacnik PW, Wilcox GL, Clohisy DR, Ramnaraine MR, Eikmeier LJ, Beitz AJ(2000) Cancer pain mechanisms and animal models of cancer pain. In: Proceedings of the 9th World Congress on Pain, 16 (Devor M, Rowbotham C, Wiesenfeld-Hallin Z, eds), pp 615-637. Seattle: IASP. Webb DJ (1997) Endothelin: from molecule to man. Br J Clin Pharmacol 44:9-20.

Zheng JH, Chen J (2001) Differential roles of spinal neurokinin 1/2 receptors in development of persistent spontaneous nociception and hyperalgesia induced by subcutaneous bee venom injection in the conscious rat. Neuropeptides 35:32-44.

Zochodne DW (2000) The microenvironment of injured and regenerating peripheral nerves. Muscle Nerve [Suppl]9:S33-S38. 